\title{
THE PECULIARITIES AND IMPACTS OF AIRPORTS: THE CASE FOR MALTA INTERNATIONAL AIRPORT
}

\author{
Lino Bianco ${ }^{1,2 *}$, ORCID: 0000-0001-8779-2351 \\ ${ }^{1}$ University of Malta, Msida, MSD 2080, Malta \\ 2University of Architecture, Civil Engineering and Geodesy, 1 Hristo Smirnenski Blvd., Sofia 1164, Bulgaria \\ *Corresponding Author: Lino Bianco, lino.bianco@um.edu.mt
}

Received: 01. 12. 2021

Accepted: 02. 18. 2021

\begin{abstract}
The small-to-medium sized Malta International Airport (MIA) is the only airport in Malta, especially in terms of its footprint, and is considered one of the world's most scenic landings, according to a 2016 poll. The annual passenger turnover is approximately 16 times the country's population. MIA's unique features include its proximity to the urban conservation area of Luqa, as well as that town's other residential and business facilities, and also to the southern coast of Malta and the unique ecological habitats it supports. Its impacts range from noise to atmosphere pollution and, potentially, pollution of the coastal waters, in the eventuality of an air traffic accident. On the basis of the national strategic vision that Malta evolves into an expanding hub in the centre of the Mediterranean, significant investment is earmarked for MIA, including initiatives impacting security, the environment and energy.
\end{abstract}

Keywords: airport, planning policy, tourism policy, heritage protection, nature protection, Luqa, Malta.

\section{Introduction}

For long-haul travel, air transport is preferred as it is usually the fastest mode of travel compared to car, bus and train - even when affected by delays - and the safest. It is vital for the tourism industry [1-2], especially regarding access to remote locations such as islands. Since the mid-1990s, there has been a rapid growth in air transport in all 27 European Union Member States and airports are being transformed into hubs for both international and domestic flights [3]. Mashhoodi and van Timmeren [4] classified European airport regions in five typologies: urban airports, urban periphery airports, agricultural-area airports, natural-area airports and remote airports (Table 1).

Malta International Airport (MIA) (Figure 1) is a small-to-medium sized facility and the only airport in the Maltese archipelago developed largely after the Second World War era. It is neither a major airport nor a large airport region, as defined by Mashhoodi and van Timmeren [4]. The country of Malta is the smallest Member State of the EU, having a total surface area of $316 \mathrm{~km}^{2}$, the main inhabited island being Malta itself. Although overwhelmingly referred to by foreigners who have never travelled to Malta as being 
located in 'La Valletta', Valletta being the island's capital city, MIA administratively falls within the confines of the town of Luqa. The island of Malta (as opposed to the country) is approximately $246 \mathrm{~km}^{2}$ in area, with a length and width of $27 \mathrm{~km}$ and $14.5 \mathrm{~km}$ respectively.

Table 1

\begin{tabular}{|c|c|c|}
\hline \multicolumn{3}{|c|}{ Typologies of airport regions of Europe (After [4]) } \\
\hline Airport typology & Characteristics & Example/s \\
\hline Urban & $\begin{array}{l}\text { Adjacent to high concentrations of } \\
\text { urban land use and population }\end{array}$ & Geneva, Zurich, Graz \\
\hline Urban periphery & $\begin{array}{l}\text { Adjacent to urban areas and high } \\
\text { concentration of industrial and leisure }\end{array}$ & Berlin, Bordeaux, Malaga \\
\hline Agricultural-area & Adjacent to agricultural land use & $\begin{array}{l}\text { Paris, Barcelona, } \\
\text { Amsterdam }\end{array}$ \\
\hline Natural-area & $\begin{array}{l}\text { Close proximity to natural areas and } \\
\text { distance from leisure, industry and } \\
\text { major road network }\end{array}$ & Milan \\
\hline Remote & $\begin{array}{l}\text { Located at a long distance from all } \\
\text { land uses and population centres }\end{array}$ & London, Nuremberg, Belfast \\
\hline
\end{tabular}
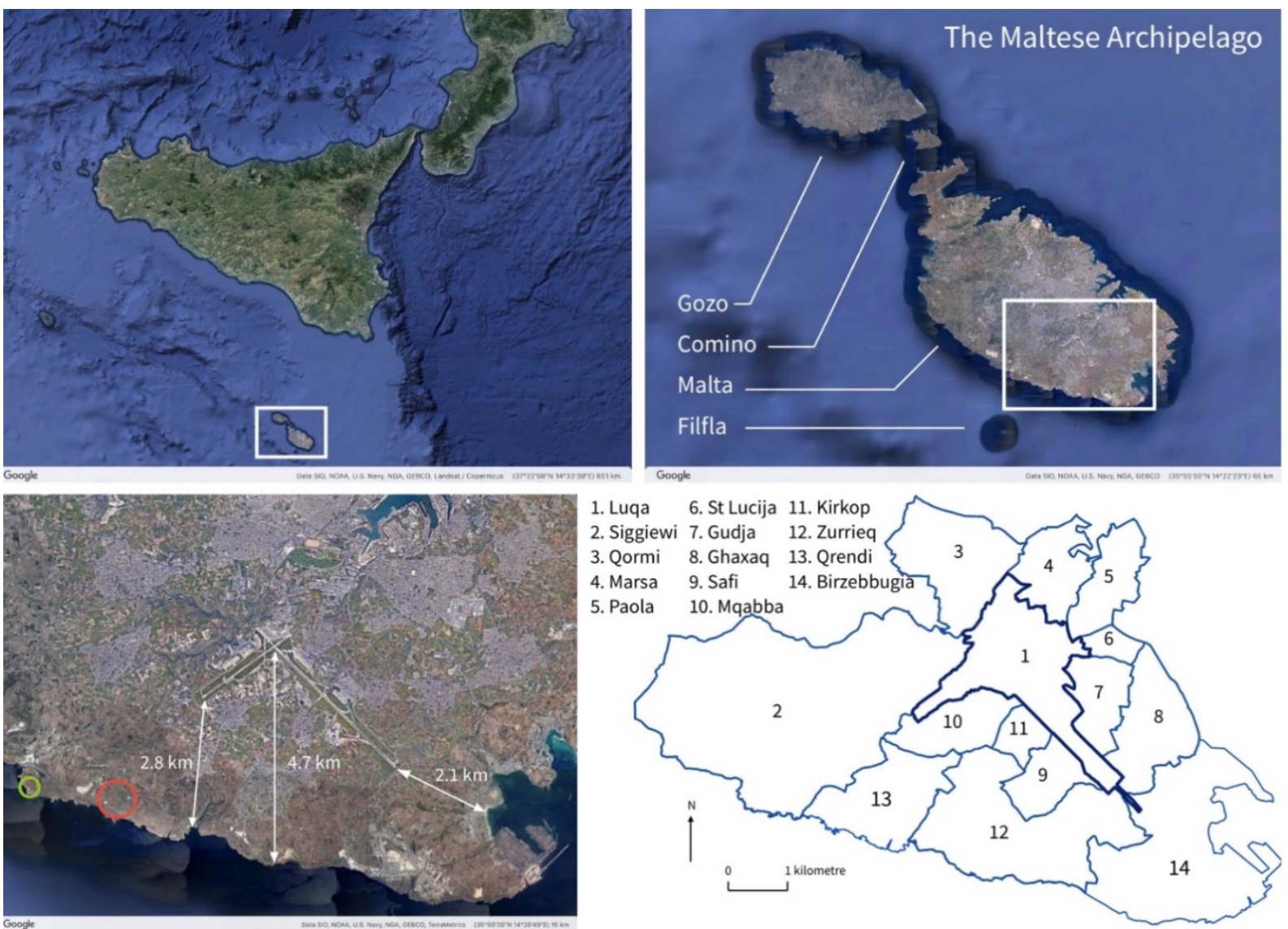

Figure 1. Site location (online version is in colour) - outlined in white - of the Maltese archipelago (top, left), Malta and its dependencies (top, right); the location of MIA with distances from the coast (bottom, left) - Hagiar Qim and Mnajdra Neolithic Temples and Lapsi Reverse Osmosis Plant are circled in red and green respectively (৫ Google Earth); the administrative boundaries of various Local Councils - including Luqa (bottom, right). 
Due to this fairly modest size, virtually all the coastline of the island is potentially exposed to the impacts of MIA (Figure 1, bottom left). Given that Luqa is located in the south of the island, the coast most exposed to risk is along the southern one, which touches the confines of the local councils of Birżebbuġa, Qrendi, Siǵġiewi, and Żurrieq (Figure 1, bottom right).

In 2019, 7.3 million passengers used MIA [5]. This figure is nearly 16 times the resident population of the island of Malta which stood at 460,171 at the end of 2018 [6, p. 15]. This represents a $7.4 \%$ increase in air passengers over 2018 , peaking, with just over 823,000 passenger movements, in August, at the height of the 'festa' or village feast season [5].

This paper addresses the characteristics of MIA and its impacts on the locality of Luqa and the wider region, characterised notably by a coastline of ecological and ornithological importance. These findings are supported by references to policies contained in relevant national development planning documents which aim to improve MIA whilst respecting the natural environs. Furthermore, it highlights current research and national investment to render the airport EU compliant.

\section{Methodology}

To tackle the themes outlined above, use was made of existing literature on the history of Luqa and its airport, together with a number of official sources, notably:

1. National and local planning policies of the Planning Authority (PA), the national regulator for development planning in Malta, which was renamed Malta Environment and Planning Authority (MEPA) during the years 2002-2016 as when it was merged with the Environment Protection Department;

2. Official statistics issued by the National Statistics Office, Malta;

3. MIA press releases; and

4. Reports of ENGO BirdLife International.

\section{Luqa and its airport}

Aviation in Malta dates back to the 1920s when the island was a fortress colony of Britain. Given its geographical position at the centre of the Mediterranean, and predicting the future importance of aerial warfare, the British Government developed three main airfields. Ta' Venzja, known as Ta' Qali (or Ta Kali or Takali) by the Royal Air Force, in heartland Malta, was the location of the first civil airfield. It was followed by those at HalFar (used by the Fleet Air Arm) and Luqa. The latter was less damaged than the others by Axis bombardment during Second World War. Unlike Ta' Qali and Hal-Far, Luqa airport was not prone to flooding.

The first civil terminal was inaugurated in Luqa in 1958. In 1977, a longer runway was constructed to accommodate an anticipated increase in air traffic, while the air terminal was refurbished and extended until it was eventually superseded by the present terminal, which was inaugurated in 1992 (Figure 2). MIA was established as the public limited company solely responsible for operating the air terminal in 1991. Its remit also included the operations and management of air traffic control, an activity hived off at the end of 2001 and transferred to Malta Air Traffic Services, an autonomous government entity [7]. MIA has two main runways with the area control tower located in between. The runways, RWY 14-32 and RWY 06-24, are set perpendicular to one another and international air traffic control operations are managed 24/7. 


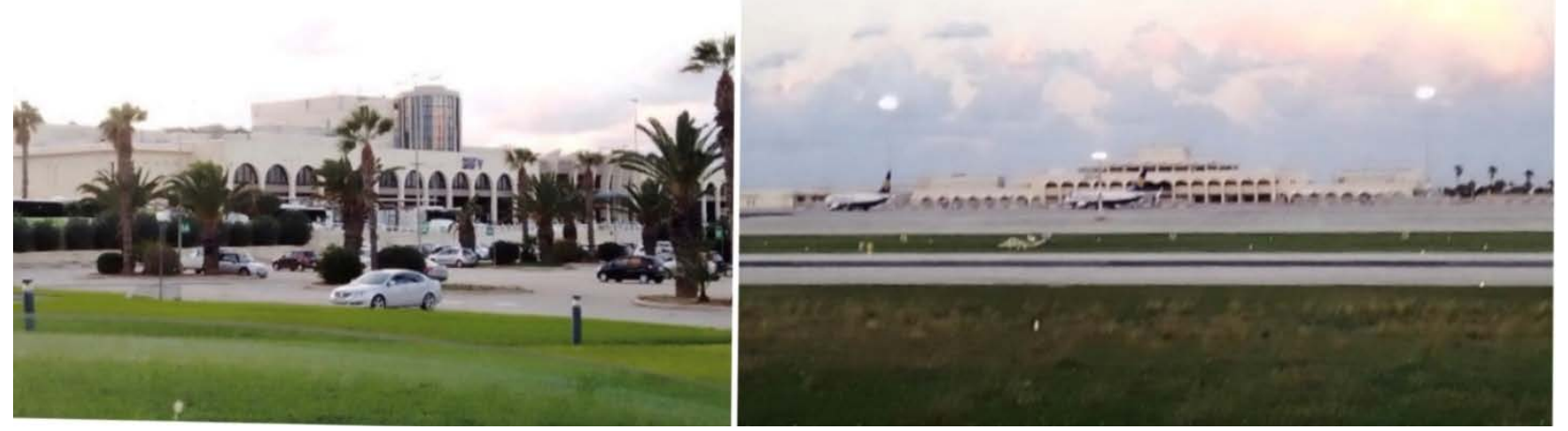

Figure 2. Terminal of MIA (online version is in colour): as at present (left), and as viewed from the side of the runway (right) (๔ Alessandra Bianco).

Under the terms of the Local Councils Act [8], the town of Luqa includes the rapidly expanding hamlet of Hal-Farrug, originally a medieval settlement which includes a historic chapel that was partly destroyed to make way for airport extensions. The constituency of Luqa, which measures circa $6.75 \mathrm{~km}^{2}$, is the major inland locality forming part of the South Malta Local Plan [9, pp. 99-104]. It is predominantly rural in character $\left(6.25 \mathrm{~km}^{2}\right.$ is countryside). Micallef [10] offers a dated but detailed study of this locality, while more recent but brief descriptions are provided by Fiott [11] and Guillaumier [12]. Luqa's urban core still retains the characteristic vernacular organic street pattern (Figure 3, left) with a baroque-style parish church in the main square (Figure 3, right), which was rebuilt after damage in the Second World War blitz. The urban areas $\left(0.48 \mathrm{~km}^{2}\right)$ are predominantly residential in nature.
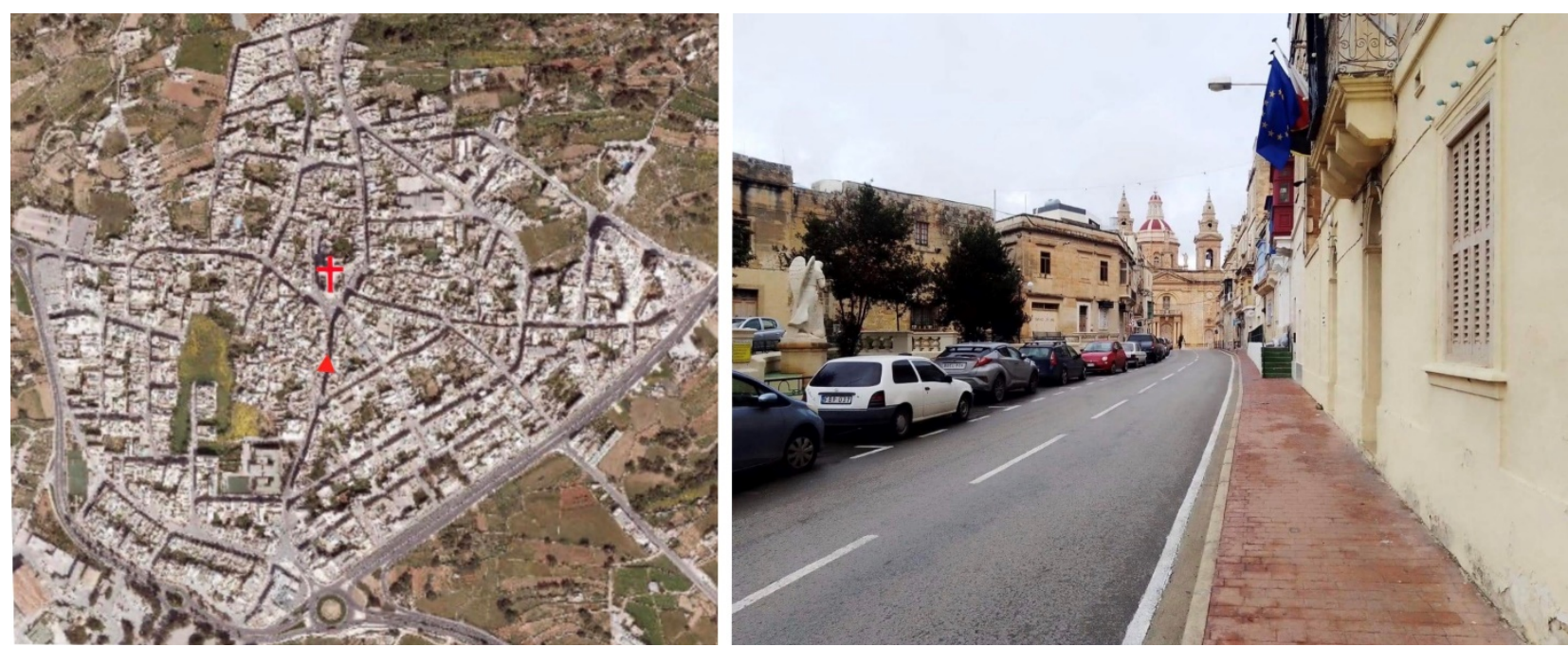

Figure 3. Luqa (online version is in colour): orthophoto of the urban area (left) (৫ Planning Authority, Malta), the position of photo and church shown in Figure 3 right, is marked by $\Delta$ and + respectively; the main street, named after the patron saint of the town, leading to the main square (for position of photo see Figure 3 left) (๑ Alessandra Bianco).

Luqa forms part of the southern harbour region. The latest demographic review, based on the 2011 (November) census, estimates its population on 31 December 2014 at 5,714 [13, p. 14] thus reversing the depopulation trend experienced in the preceding years. A decade earlier, in 2004, it stood at 5,195 [14, p. 15] whilst in 2001 it was 5,456 [15]. 
Important institutions located within the Luqa Local Council (LLC) area include St Vincent de Paule Residence, the main state home for the elderly in Malta, and the Research and Agricultural Development Centre at Ghammieri. Other facilities include The Malta College of Arts, Science and Technology Agribusiness Institute, the main premises of the Water Services Corporation and a medium-sized industrial park.

\section{The southern coast of Malta}

In the PrivateFly Best Airport Approaches 2016 poll conducted in early 2016, MIA was listed as one of the world's most scenic landings. The CEO of PrivateFly, Adam Twidell, himself an experienced pilot, commented that: "Flying into Malta is a truly special experience - it's a tiny island landing that packs a big punch. There is so much to take in. Without being hectic, the landscape changes from coast, to farmland, to the historic city of Valletta. It's like flying into a Picasso painting" [16].

The geology and geomorphology along the southern coast of Malta are shown in Figure 4. Lower Coralline Limestone cliffs, formed in the Oligocene, characterise most of this coast. Under the Structure Plan for the Maltese Islands [17], the cliffs are scheduled by the PA as Level 2 Areas of Ecological Importance and Areas of High Landscape Value [18]. The geological formations are horizontally bedded. Where the overlying Globigerina Limestone occurs, weathering is more pronounced and exhibits diagnostic weathering features mapping out the varying lithostratigraphic beds.

The Lower Coralline Limestone formation forms an extensive aquifer extending, at sea-level, beneath most of the island. Given the littoral character of the southern coast, no special protective measures to conserve the integrity of this aquifer are necessary as the continuous seawater intrusion reduces the quality of the groundwater along coastal zones. Thus, any potential impact of MIA, if applicable, would be negligible. These areas lie outside the designated water protection areas as established by the Water Services Corporation, the former body protecting the islands' groundwater resources since 1992. In 2000, the Malta Resources Authority became the authority responsible for managing and protecting the islands' aquifers. The sea-cliffs of southern Malta support maritime rupestral vegetation assemblages typical of coastal cliffs. Since they are largely inaccessible, they are still in pristine condition and provide an ecological refuge to many species of flora and fauna, a large number of which are endemic [19] and thus are of significant ecological, biogeographical and conservation value.
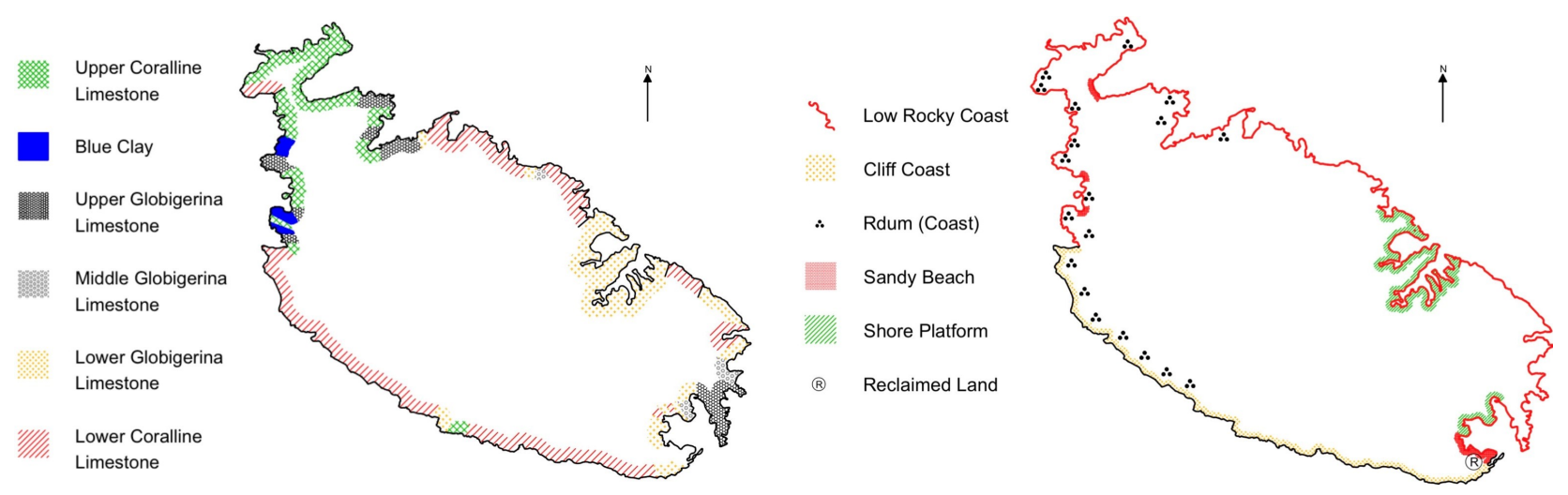

Figure 4. Malta: coastal geology (left) and geomorphology (right) (online version is in colour). 
There are two species of Procellariidae that nest in the Maltese Islands: Cory's shearwaters (Calonectris diomedea diomedea [Scopoli], Maltese Ċiefa) and Levantine shearwaters (Puffinus puffinus yelkouan [Acerbi], Maltese Garnija). The southern coast supports the largest concentration of Cory's shearwaters in Malta, with more than 1,000 breeding pairs, along with more than 200 pairs of Levantine shearwaters. The breeding population of Cory's shearwaters in the Maltese Islands is estimated at around 7,000 breeding pairs, distributed along the southern coast of Malta, Gozo, Comino and Filfla. The southern cliffs between Benghajsa point and Ghar Lapsi support the largest concentration on mainland Malta [20]. Back in 1994, due to a large decline in numbers, Cory's shearwaters were designated as Category 2 - vulnerable according to Species of European Conservation Concern [21]. Since then, numbers have recovered significantly, and they are currently listed as a species of 'least concern' according to The IUCN Red List of Threatened Species [22]. At a more local level, the species was designated as vulnerable with a restricted distribution in the Mediterranean. The Levantine (or Yelkouan) shearwater has a similar national status as Cory's Shearwater. The IUCN Red List of Threatened Species 2018 [23] has them marked as vulnerable.

Further to pristine, ecologically rich, valleys such as Wied iż-Żurrieq (Figure 5, left), a considerable number of archaeological and historical remains are located along the southern coast of Malta. These reflect how the island's history is intertwined with its natural configuration [19]. Amongst these remains are Haǵar Qim (Figure 5, right) and Mnajdra Neolithic Temples (Figure 1, bottom left), acknowledged as World Heritage sites by UNESCO [24].

\section{Strategic planning policies}

The strategy of the PA with regards to Luqa is to protect its rural character whilst making provision for recreational facilities, in particular within the limits of the medieval settlement of Hal-Farrug. With respect to the airport, the PA's strategy is for MIA to develop into a regional hub and consolidate various activities within its existing footprint.

Strategic planning policies for the Luqa area are included in the South Malta Local Plan [9]. Policy SMLU 07 states that "For the area designated as the Malta International Airport Master Plan Area, as indicated in the Luqa Airport and Environs Policy Map LU 3, a Master Plan is to be submitted to MEPA by the Malta International Airport indicating the various developments and uses proposed for this area which may include facilities relating to airport operations, retail and commercial facilities, entertainment facilities, parking, as well as an element of tourist accommodation".

The Strategic Environmental Assessment: Environment Report [25], prepared as part of Strategic Plan for Environment and Development, which replaced the Structure Plan for the Maltese Islands [17], makes only passing reference to the airport. It states that there is a regulation governing noise emissions from airports (Paragraph 4.8.2) and declares, in Thematic Objective 12, that (i) the land around the airport must be safeguarded for future expansion of aviation-related activities and (ii) the transport network serving the airport must be satisfactory to accommodate such an expansion.

Given the presence of MIA, non-urban areas, which account for approximately $93 \%$ of the territory of the LLC, are taken up by facilities associated with airport operations: namely, runways, passenger terminals, airport administrative blocks, aircraft workshops and ancillary facilities. 

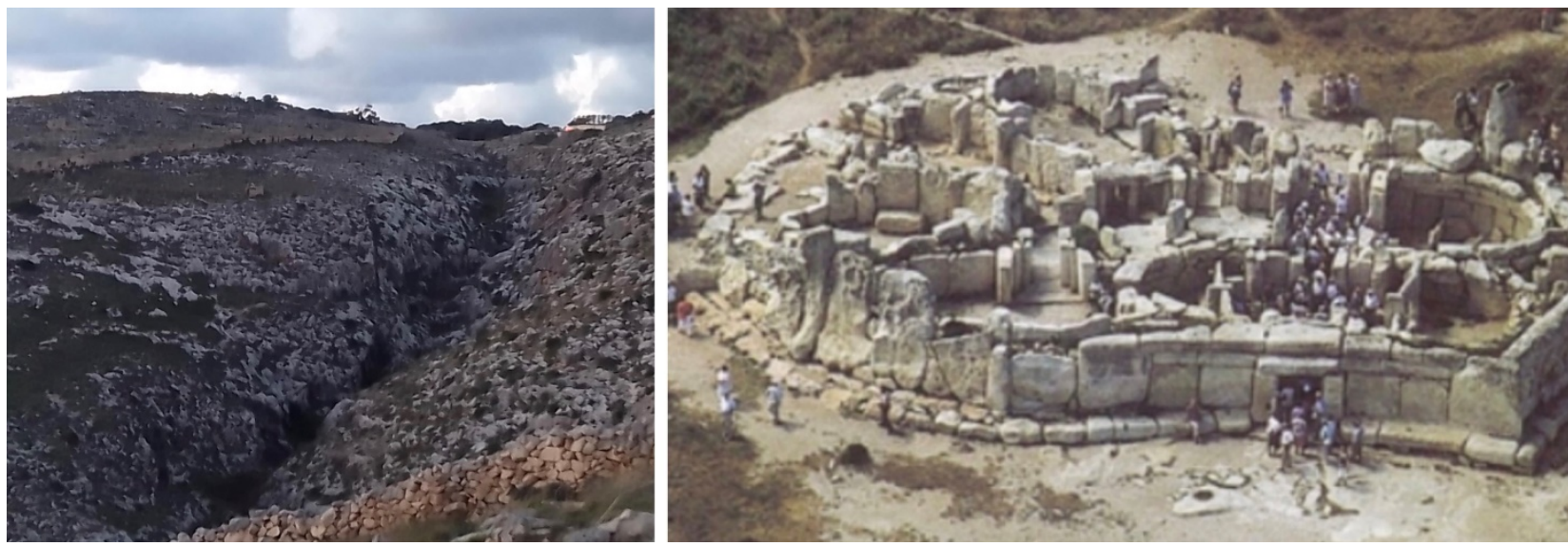

Figure 5. Wied iż-Żurrieq, one of the pristine, ecologically rich, valleys in Malta (left); dated aerial photo of Hag̉ar Qim Neolithic Temples (right) (Hagar Qim by peuplier is licensed under CC BY 2.0) [26], (online version is in colour).

Future development planning proposals include a new air approach route for the airport and commercial and recreational facilities. Furthermore, due to the presence of the airport, Luqa is subject to significantly high traffic levels from localities south of the airport as well as from the central and northern parts of the island and from Malta's sister island of Gozo.

Neither general nor specific policies related to tourism in Luqa are contained in the South Malta Local Plan, despite the fact that a number of archaeological and historical remains occur within the territory of the Local Council. For example, Roman catacombs that interfered with the various developments and upgrades of airport facilities were destroyed and/or made inaccessible. The plan does identify various archaeologically sensitive areas, some of which occur within the airport area and are included in Maps LU7 and LU8 [27]. These historical remains include chapels and other architectural elements, as well as works of art.

Cultural heritage, both in terms of architecture and folk traditions, has long been noted by the LLC as a source of identity for the locality. Luqa's architectural heritage is important, as are traditional activities such as band clubs and the village 'festa'. The Local Council supports such assets which have expanded over a number of decades because it understands that such traditions and practices should complement and not compete with economic growth. Accordingly, LLC developed a policy whereby tourism is encouraged and sustained. Tourism is not seen by the Local Council as an end in itself but as a means to an end, namely, to sustain and improve on the otherwise healthy socioeconomic fabric of the locality.

While accepting that MIA cannot be separated from Luqa, since the latter encompasses the former while giving it distinctiveness, LLC is aware of the environmental impacts of noise and air pollution from air traffic on the socioeconomic sphere and cultural heritage of the locality. As elsewhere, awareness is growing about environmental and health issues that are taking their toll on the local community. The Local Council's response is to take a proactive stand vis-à-vis present and future airport area planning strategies, to ensure that the environmental conditions and health of the community are improved whilst encouraging the sustainable development of the area's tourism potential as a means of sustaining this identity. 


\section{Unique features and impacts of MIA}

Aircraft activity involves the arrival, parking and disembarkation of passengers, the unloading of baggage and cargo, and maintenance activities. Prior to departure, maintenance and engine testing is carried out, after which the passengers board, baggage is loaded and the plane refuelled. Thus, the main impacts of airport activity go beyond noise, vibration and related issues, to include light, air, soil and water pollution.

The arrival and departure of an aircraft emits noise and has transboundary impacts on air quality due to the generation of air pollution throughout the flight. Once an aircraft lands, it parks, emitting further noise and exhaust gases. Any handling vehicles required for baggage loading, passenger dis/embarkation, cleaning and maintenance works generate exhaust fumes and noise. The road traffic to and from the airport also has an impact on air quality. Runway activity is associated with light pollution, especially in view of Luqa's rural location. The maintenance of airport's external facilities - the two runways, aprons, fuel depots, aircraft maintenance garages and landscaped or turfed areas - also has impacts on the environment, as does the provision of energy for runway lighting and fire drills. The airport terminal is a centre of activity which continuously consumes energy and water, and generates waste.

Noise impacts negatively on both residents and birds, and light pollution may interfere with the night sky, affecting the circadian rhythms of wildlife and potentially deterring shearwaters from reaching their colonies sited along the coastal cliffs [28]. Light pollution also has the effect of attracting moths and insects, thus reducing food sources for bats [29] and other night-time predators that rely on them. Due to the fact that Luqa airport is a protection zone where bird trapping and hunting is not permitted, and because Malta is located on the main migratory route across the Central Mediterranean, birds often seek shelter within the precincts of MIA. This in itself carries its specific risks; for example, flocks of starlings (Sturnus vulgaris, Maltese Sturnell) or gulls (Larus sp., Maltese Gawwi) often interfere with air navigation and pose a potential hazard to aircraft, especially during takeoff.

Located in the town of Sigg giewi, the Lapsi Reverse Osmosis Plant lies along the coast just south of the airport (Figure 1, bottom left). If an air crash occurred at sea in the vicinity of this plant, there is a high probability of sea contamination, which would have a severe negative impact on the production of potable water. This reverse osmosis plant is the second largest desalination plant in the Maltese archipelago, contributing nearly a tenth of the supply of potable water.

\section{Research and investment}

Local and foreign studies have been undertaken on how to reduce the impact of flights on the environment through improved flight efficiency. A fairly recent one by Micallef et al [30] shows that fuel burn and $\mathrm{CO} 2$ emissions by inbound flights can be reduced if other approach routes are exploited for MIA's main runways, a theme which is being considered in contemporary literature relating to flight trajectory optimization (e.g., [31]). This suggestion is in line with MIA's corporate social responsibility agenda. Other considerations include using electric vehicles to tow airplanes onto the runway, instead of them taxiing powered by their own, highly polluting engines. At present, research is being undertaken at the University of Malta for engineless aircraft taxiing through Situation Awareness and Traffic Management for Engineless Taxiing (SAMET) project [32]. 
A number of measures taken by MIA to improve sustainability, ranging from energysaving lighting and air conditioning to the installation of more efficient sanitation systems, led to the airport lowering its greenhouse gas emissions by $12 \%$ and its total water consumption by $11.6 \%$ in 2018 [33]. In early 2020, MIA announced a multi-million euro investment in terminal expansion which, further to the physical increase of its footprint, will include "smart technologies, including a new building management system to allow for energy and water management optimisation, and better insulation [...] which will play an important role in the company's journey towards the achievement of carbon neutrality" [34].

The latest investment by MIA involves upgrading its security and IT infrastructure. A multi-million EU-financed investment is aimed at tightening controls and data sharing at Malta's external borders through the EU Travel Information Authorization System (ETIAS). In a press conference announcing the project, the Home Affairs Minister stated: "Malta's borders are some of the most frequently crossed in the EU, so it is essential that our frontier management systems are up to scratch, both for the sake of our national security as well as the safety of the EU" [35].

\section{Conclusions}

A small-to-medium-sized facility which dates back to the late 1950s, Luqa airport is neither a major airport nor a large airport region. Located near the southern coast of Malta and in close proximity to the residential areas of the town of Luqa, a number of conclusions can be drawn with regarding MIA.

With respect to the southern coast of Malta:

1. impacts on the aquifer are negligible;

2. the maritime rupestral vegetation assemblages typical of coastal cliffs are not affected;

3. the two species of Procellariidae - Cory's shearwaters and Levantine shearwaters - may be negatively affected; and

4. given that a major reverse osmosis plant is located along this coast, in the case of an air crash at sea, contamination of sea water would have a significant negative effect on national water production.

With respect to the locality of Luqa:

1. aircraft noise impinges negatively on locals and birds;

2. light pollution generated at MIA negatively interacts with circadian rhythms of wildlife and is likely to deter shearwaters from reaching their colonies along the cliffs; and

3. flocks of starlings or gulls, which often interfere with air navigation, pose a potential hazard to aircraft.

In terms of national planning policies, MIA will remain at Luqa for decades to come. Environmental planning research is being undertaken to reduce the impacts of aircraft navigation on the natural and residential environs. Measures to improve sustainability and lower greenhouse gas emissions are being undertaken. Furthermore, significant investment, in part EU-financed, is projected in the immediate future to ensure an EU-compliant strategy for security and IT infrastructure.

MIA is a top contributor to the local economy. It supports not only the physical and economic wellbeing of its employees but also the social and environmental initiatives of surrounding localities. Some initiatives were taken within the local community of Luqa 
through the Malta Airport Foundation, which has partnered with NGOs on various marine conservation projects [5].

Acknowledgments. This article is based on two presentations by the author, as the environmental planning consultant of Luqa Local Council, at the first town-twinning conference entitled 'Airport Cities in the Union' held on 12-15 October, 2005 in Fiumicino, Italy. Joanne Bianco Muscat, an environment planning consultant, assisted the author in the preparation of the aforementioned presentations. The author would like to express his gratitude to Alessandra Bianco for granting him permission to reproduce Figures 2, 3 right and 5 left.

\section{References}

1. Barros C.P. Airports and tourism in Mozambique. In: Tourism Management, 2014, 41, pp. 76-82.

2. Castillo-Manzano J.I. Determinants of commercial revenues at airports: Lessons learned from Spanish regional airports. In: Tourism Management, 2010, 31, pp. 788-796.

3. Merkisz-Guranowska A., Bieńczak M., Kiciński M., Zmuda-Trzebiatowski P. Location of airports - selected quantitative methods. In: LogForum, 2016, 12(3), pp. 283-295.

4. Mashhoodi B., van Timmeren A. Airport location in European airport regions: Five typologies based on the regional road network and land use data. In: Data in Brief, 2020, 29, 105317.

5. Malta International Airport. Record 7.3 million passengers passed through Malta International Airport in 2019. [online]. 08.01.2020. [accessed 28.11.2020]. Available: https://www.maltairport.com/record-7-3-millionpassengers-passed-malta-international-airport-2019/

6. National Statistics Office. Regional Statistics Malta: 2020 Edition. Valletta, National Statistics Office. [online]. $2020 . \quad$ [accessed 15.11.2020]. Available: https://nso.gov.mt/en/publicatons/Publications_by_Unit/Documents/02_Regional_Statistics_(Gozo_Office)/2 020/Regional_Statistics_Malta-2020\%20Edition.pdf

7. Cremona J. The Privatisation of the Malta International Airport and its Financial Implications. B.Comm. (Hons) Dissertation. Malta: University of Malta, 2011. [accessed 27.11.2020]. Available: https://www.um.edu.mt/library/oar/bitstream/123456789/3467/1/11BACC034.pdf

8. Laws of Malta. Local Councils Act, 1993.

9. Malta Environment and Planning Authority. South Malta Local Plan. Marsa, 2006, Vol. l.

10. Micallef G. Hal Luqa: Niesha u grrajjietha. Zabbar, Malta: Veritas Press, 1975.

11. Fiott C. Town and Villages in Malta and Gozo; Part 2: The South. Rabat, Malta: Conventual Franciscans, 1996.

12. Guillaumier A. Bliet u Rhula Maltin. Vol. 1, Sta Venera, Malta: Klabb Kotba Maltin, 2002.

13. National Statistics Office. Demographic Review 2014. Malta: Government Printing Press, 2016.

14. National Statistics Office. Demographic Review 2004. Malta: Government Printing Press, 2005.

15. National Statistics Office. Demographic Review 2001. Malta: Government Printing Press, 2002.

16. Malta International Airport. Malta International Airport tops list of world's most scenic airport landings. [online]. 2016. [accessed 28.11.2020]. Available: https://www.maltairport.com/malta-international-airporttops-list-worlds-scenic-airport-landings/

17.Planning Services Division. Structure Plan for the Maltese Islands: Draft Written Statement and Key Diagram. Malta: Ministry for Development of Infrastructure, 1990.

18. Department of Information. Government Notice GN_400_1996. In: The Malta Government Gazette, 25 June 1996, pp. 4116-4120.

19.Planning Authority. Coastal Strategy Topic Paper - Final draft. Floriana, 2002. [accessed 15.11.2020]. Available: https://discomap.eea.europa.eu/map/Data/Milieu/OURCOAST_032_303_MT/OURCOAST_032_303_MT_Doc2 MTCoastalStrategy.pdf

20. Borg J. Ornithology. In: Lino Bianco \& Associates, ed Environmental Impact Statement: Tuna Penning Farm off Benghajsa Reef, Malta. Malta, 2001, pp. 2.88-2.92.

21. Tucker, G.M., Heath, M.F. (ed). Birds in Europe: Their Conservation Status. BirdLife Conservation Series No. 3. Cambridge, United Kingdom: BirdLife International, 1994. 
22. Birdlife International. Calonectris diomedea. The IUCN Red List of Threatened Species 2015: e.T45061132A66727878 [online]. 2015. [accessed 21.12.2020]. Available: https://www.iucnredlist.org/species/45061132/66727878

23. Birdlife Interntional. Puffinus yelkouan. The IUCN Red List of Threatened Species 2018: e.T22698230A132637221 [online]. 2018. [accessed 21.12.2020]. Available: https://dx.doi.org/10.2305/IUCN.UK.2018-2.RLTS.T22698230A132637221.en

24. UNESCO. Megalithic Temples of Malta. [accessed 15.11.2020]. Available: https://whc.unesco.org/en/list/132/

25. Malta Environment and Planning Authority. Strategic Environmental Assessment: Environment Report. Floriana, 2015.

26.PEUPLIER. Hagar Qim. [image]. [accessed 12.01.2021]. Available: http://www.flickr.com/photos/peuplier/3019403075/

27. Malta Environment and Planning Authority. South Malta Local Plan. Marsa, 2006, Vol. 2.

28. Raine H., Borg J., Raine A.F., Bairner S., Borg Cardona M. Light Pollution and its Effect on Yelkouan Shearwaters in Malta; Causes and Solutions. [online]. 2007. [accessed 03.01.2021]. Available: https://www.researchgate.net/publication/242353437_Light_Pollution_and_its_Effect_on_Yelkouan_Shearw aters_in_Malta_Causes_and_Solutions

29. Patriarca E., Debernardi P. Bats and light pollution. [online]. 2010. [accessed 03.01.2021]. Available: https://www.researchgate.net/publication/265079641_Bats_and_light_pollution

30. Micallef M., Chircop K., Zammit-Mangion D., Sammut A. Revised approach procedures to support optimal descents into Malta International Airport. In: CEAS Aeronautical Journal, 2014, 5(4), pp.461-475.

31. Murrieta-Mendoza A., Ruiz H., Botez R.M. Horizontal flight trajectory optimization considering RTA constraints. In: MATEC Web of Conferences, 2020, 314, 02002. https://doi.org/10.1051/matecconf/202031402002

32. University of Malta. Situation Awareness and Traffic Management for Engineless Taxiing (SAMET) project. [accessed 23.12.2020]. Available: (https://www.um.edu.mt/iat/ourresearch/fundedprojects/satmet

33. Malta International Airport. Solar energy and water-saving systems help Malta International Airport reduce its ecological footprint. [online] 2019. [accessed 28.11.2020]. Available: https://www.maltairport.com/solarenergy-and-water-saving-systems-help-malta-airport-reduce-its-ecological-footprint/

34. Malta International Airport. Malta International Airport kicks off the terminal expansion project. [online]. 29.01.2020. [accessed 28.11.2020]. Available: https://www.maltairport.com/malta-international-airportkicks-off-terminal-expansion-project/

35. Delia J. $€ 13.6 \mathrm{~m}$ to be invested in airport security infrastructure: Home Affairs Minister announces EUfinanced overhaul. In: Times of Malta (28 November). [online]. 2020. [accessed 10.12.2020]. Available: https://timesofmalta.com/articles/view/136m-to-be-invested-in-airport-security-infrastructure. 834875 